\title{
Sediment budget and morphological evolution in the Bay of Mont-Saint-Michel (Normandy, France): aerial (LIDAR) and terrestrial laser monitoring
}

\author{
Gluard Lucile', lucile.gluard@unicaen.fr \\ Levoy Franck ${ }^{1}$, Bretel Patrice ${ }^{1}$, Monfort Olivier ${ }^{1}$, \\ 1 Morphodynamique Continentale et Côtière UMR6143 Université de Caen - CNRS \\ 2-4, rue des Tilleuls - 14000 CAEN - FRANCE
}

\begin{abstract}
We propose a study on the use of laser techniques to monitor altimetric variations in the tidal flat of the Bay of Mont-Saint-Michel. The Bay of Mont-Saint-Michel has been strongly anthropised. Because of impoldering, wandering rivers were not able to sap salt-meadow and modern tidal flooding of the Mont-Saint-Michel has lowered. Through modern studies and projects aimed at restoring the marine nature of the bay it appears that flushes are useful to discard sediment tending to silt the bay. The major aim of our work consists in the better understanding of the effect of the dam built recently (May 2009) in that purpose. Laser scanning is commonly used for topographic surveys and the generation of Digital Elevation Model (DEM). Repeating surveys, allow to quantify topographic changes and therefore sediment budgets. Our study is based on aerial topographic surveys of the intertidal zone acquired before the operational start up of the dam (in 1997, 2002, 2007 and February 2009). Sediment budgets computations confirm that the bay tends to accrete but annual rates quite variable in time. The value computed between 2002 and 2007 is 2.3 times and 3.5 times smaller than the deposition rates computed for the 1997/2002 and 2007/2009 periods. Terrestrial laser surveys acquired on a more restricted area after the beginning of the flushes are also used in a more qualitative way to investigate their impacts. The preliminary results show that flushes allow to reduce sediment deposition but also that their efficiency is geographically contrasted. Another remarkable result consists in the identification of coastal dynamics: location of erosion versus deposition zones, of evolutions of vegetation cover and drainage channels activity.
\end{abstract}

Keywords: Lidar, terrestrial laser scanner, sediment budget, Bay of Mont-Saint-Michel 


\section{Introduction}

The Bay of Mont-Saint-Michel, registered as a UNESCO heritage in 1979, has been strongly anthropised for a long time. It is a sheltered environment and like other bays it is subjected to a significant sedimentation. This silting-up is the result of the Flandrian transgression that swept through the coastline indentations during the sea level rising. Currents bring into those indentations sediments that accumulate, seal the bay and advance the coastline seaward. Furthermore, empoldering operations performed for agricultural purposes during the $X I^{\text {th }}$ century enhanced the concentration and deposition of sediments around the Mont-SaintMichel (LCHF 1971, Larsonneur 1989). Between 1958 and 1997, 30 million $\mathrm{m}^{3}$ of sediments settled down causing a ground rise by up to $3 \mathrm{~m}$ and allowing the salt meadows growth. Only the wandering rivers have an erosion role in this depositional environment.

In the 70ies, with the growing awareness of the threat to the marine nature of the Mont-SaintMichel, of its patrimonial value and of ecological constraints (wet zones, decrease of the agricultural surfaces...) studies were conducted to understand processes acting in the bay (tidal wave, currents, waves, rivers' flow, winds...) and a project; financed by the French State and the "Syndicat Mixte de la Baie du Mont-Saint-Michel", and called "Rétablissement du caractère maritime du Mont-Saint-Michel" (i.e. "Restoring of the maritime character of the Mont-Saint-Michel") was initiated. A new dam, used to perform water flushes and operational since May 2009, is the central feature of this project. To understand the effect of the flushes on the zone altimetry, topographic measurement campaigns have been planned. Laser techniques have the advantage to allow the efficient coverage of wide zones, difficult to access by traditional terrestrial levelling methods. So we propose a study on the use of aerial and terrestrial laser scanning to monitor changes inferred by the flushes in the tidal flats of the bay.

\section{Settings}

\section{Study area}

\subsubsection{General description}

The present study was performed in the Bay of Mont-Saint-Michel. It is located along the English Channel on the French coast, between the Cotentin Peninsula (oriented N-S) and the Brittany coast (oriented E-W).

This bay is characterized by its large $\left(\sim 500 \mathrm{~km}^{2}\right)$ sandy tidal flat incised by three rivers (the Couesnon River, the Sée River and the Sélune River), (Fig. 1).The field site is a fine example of a megatidal environment. A tidal range of $15 \mathrm{~m}$ (Le Rhun, 1982; Tessier, 1993; Larsonneur, 1994; Bonnot-Courtois et al., 2002; Cayocca et al., 2006; Billeaud et al., 2007) is observed in the bay during exceptional spring tides $\left(5^{\text {th }}\right.$ world rank after the Bay of Fundy in Canada, Puerto Gallegos in Argentina, the Severn estuary in England and the Frobischer Bay in Canada). The connecting between the resonance and sysygie phenomenon allows the existence of those high ranges. The tidal wave is semi-diurnal. It is dominated by the M2 (semi-diurnal) harmonic; the amphidromic point of which is a virtual one located on land in 
southwest England (Pingree and Griffiths, 1979). As a result, of this inland location, the tidal range is much lower along the southwest coast of England than along the adjacent French coast. At each spring tide, five billion $\mathrm{m}^{3}$ of seawater cross the lines between the Pointe du Grouin, the Chausey Islands and Granville. Tidal currents play an essential role in the transport and distribution of subtidal sediments (Larsonneur, 1989). During the flood, tidal currents progress towards the inner bay with strong intensity larger than $1 \mathrm{~m} / \mathrm{s}$. Near the Mont-Saint-Michel, the tide invades the outlet of the Couesnon River and the large tidal flat. Ebb currents are always lower than flood ones (Bonnot-Courtois et al., 2002). However, the duration of the ebb is 1.17 time longer than that of the flood (Migniot, 1997).

In the Bay of Mont-Saint-Michel, prevailing winds are usually from west to northwest, according to the median axis of the bay.

The topography of the bay (large sandy tidal flat becoming a pseudo-cohesive tidal flat on the upper part, and salt marshes) is complicated by several channels. A regional deposit called the «tangue» characterizes the upper intertidal area. It is a very fine detrital sediment ( $\varnothing$ from 30 to $120 \mu \mathrm{m}$ ), generally described as muddy fine sand. It contains more than $50 \%$ of carbonate mainly of bioclastic origin. As a result, the tangue is a sediment that can be easily drained and quickly compacts (Bonnot-Courtois et al., 2002). It is also a thixotropic sediment, easily reworked by strong tidal currents. The upper slikke and the schorre are incised by meandering secondary drainage channels. They form environments of sheltered low energy deposits, susceptible to filling themselves quickly and so to favour accretion. The presence of halophile vegetation (Spartina Anglica and Puccinellia Maritima) on the upper part of the slikke favours depositional accretion and storing of suspended sediment when covered by tides (Neumeier and Amos, 2006). The low and mid-intertidal areas are characterised by a coarse sandy material whose grain size is about $150 \mu \mathrm{m}$.

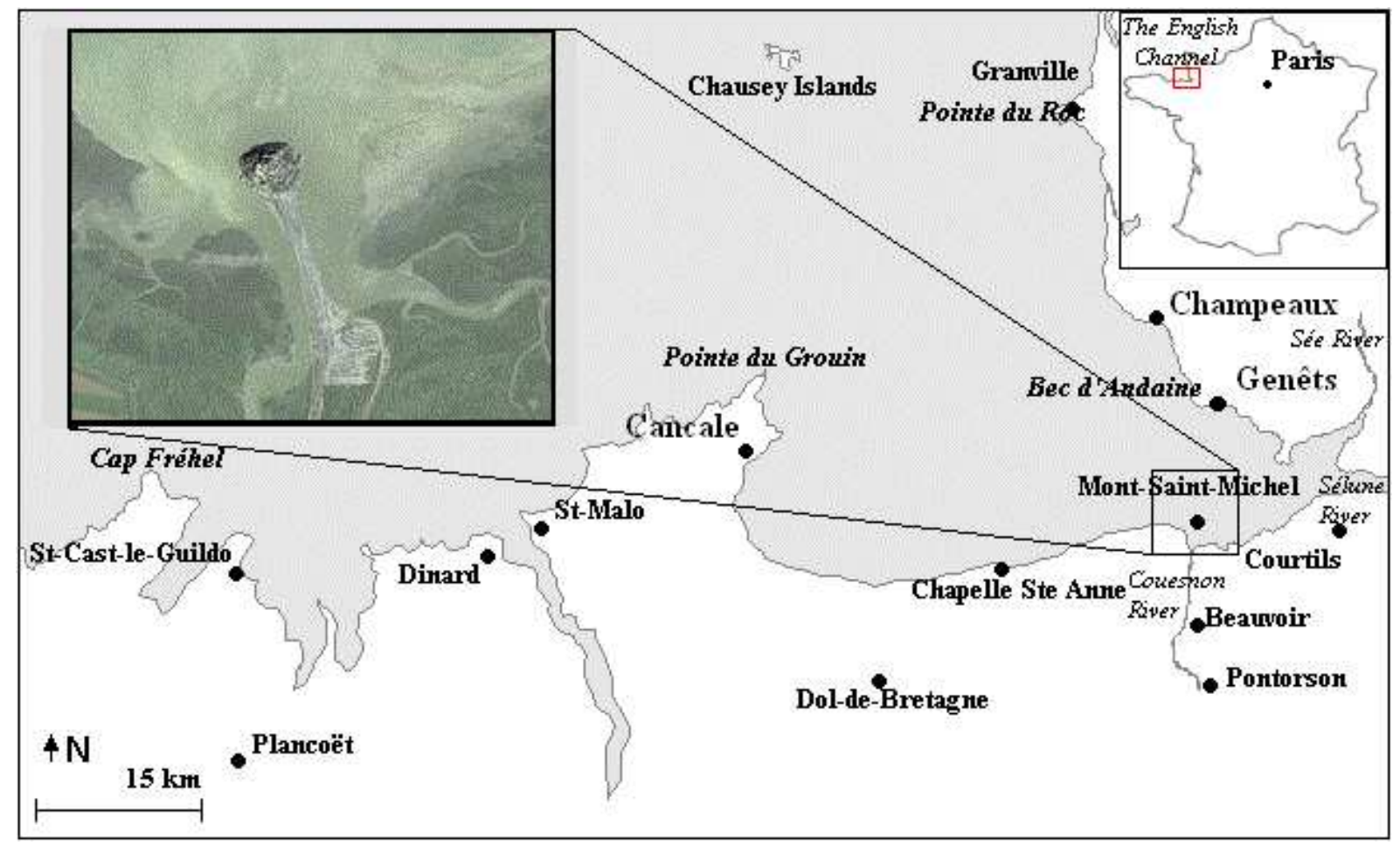

Fig. 1. Field site 


\subsubsection{Coastal arrangements}

The civil engineering works intended to limit the influence of the sea in the bay (Fig. 2).

For more than 1000 years, man has built polders for agriculture. Several polders have been destroyed till 1857 because of wandering rivers that undermine banks. Therefore, the Couesnon River has been channelised in 1863. A sea wall, west-east oriented and named "La Roche Torin sea-wall" had been built between 1857 and $18611.5 \mathrm{~km}$ East of the MontSaint-Michel to protect polders from the Sélune River wanderings. Those works increased the polder's surface by filling the area with more than $1.10^{6} \mathrm{~m}^{3}$ of tangue and sand between 1858 and 1934. Then, man built a sea wall road, between 1878 and 1879, to increase the accretion rate in the polderised zone and make a permanent access to the Mont-SaintMichel. This work impeded the tidal wave circulation all around the Mont-Saint-Michel and limited the wanderings of the Couesnon River (even limited they were). In 1969, a dam was built in La Caserne village to drain polders which prevented the flood from entering upstream. So, the Couesnon River lost its power and could not sap salt-meadows anymore. Consequently, the altimetry is higher and higher, and the tidal wave reaches less and less the Mont-Saint-Michel. A need for the restoration of the marine nature of the Bay of MontSaint-Michel is evident for economical, environmental and recreational reasons. The first step in this way was the arasement of La Roche Torin sea wall in 1984. As a recent way of thinking, the restoration has to be soft - environmentally and economically. In order to restore the accommodation space of the Couesnon River, its eroding power and a marine environment to the Bay of Mont-Saint-Michel, several works have to be built. A new dam started working in May 2009. This work allows flushes $\left(10 \mathrm{~m}^{3} / \mathrm{s}\right)$ able to remove sediments out of the bay. It works twice a day, 6 hours after the high tidal level and can unload from $70.10^{3}$ to $1700.10^{3} \mathrm{~m}^{3}$ of water. To restore the tidal current around the Mont-Saint-Michel, a new sea wall road will be built with a $1000 \mathrm{~m}$ long footbridge before the ramparts. In order to separate the flush flow, a division threshold of $+4.5 \mathrm{~m}$ IGN69 has been realised. It will be linked with different bars that will accentuate the meandering of the East and West channels. A digitised water reservoir has to be dug in Moidrey to trap $1.5 .10^{6} \mathrm{~m}^{3}$ of water.

Therefore, the sedimentary budget depends on the efficiency of the new dam flushes and marine inputs.

\subsection{Methodology}

In large and inhospitable (quicksands, high tidal ranges...) environments, laser scanning has become a convenient technique for topographic surveys (Mason et al., 2010).

Terrestrial and aerial scanner data are used in order to quantify the evolution of the topography of the studied area. Before our study, surveys have already been done: i) A photogrametric one, in 1997, served as base for the wedging of numerical and physical models realized by SOGREAH society within the framework of the "Project of the restoring of the maritime character of the Mont-Saint-Michel" in the 90ies. There is one point each $100 \mathrm{~m}$. ii) In 2002, Total Elf Fina and Ifremer realized a Lidar survey of the bay with a $\sim 20 \mathrm{~m}$ point 
density. iii) In 2007, the FIT Conseil society conducted a Lidar survey for the "Syndicat mixte de la Baie du Mont-Saint-Michel" and there is approximately one point each $1 \mathrm{~m}$. In our study we decided to have a more regular sampling i.e. one survey by month, at the rate of twice a year for Lidar survey and ten times a year for terrestrial scanning. Lidar surveys are conducted via the CLAREC project ("Contrôle par Laser Aéroporté des Risques Environnementaux Côtiers »). There is one point each square meter on average. For the moment, three surveys were realized, in February 2009, September 2009 and April 2010 (only the first one has been processed). The terrestrial laser scanner is installed in the bell tower of the abbey of the Mont-Saint-Michel. At present, six surveys were conducted on a more restricted area, in July 2009, August 2009, October 2009, January 2010, March 2010 and May 2010. Those data allow the generation of DEM. Those obtained from aerial surveys are used to compute sediments budgets on the $40.13 \mathrm{~km}^{2}$ of the common zone. The comparison between two successive terrestrial laser scanner surveys allows the appreciation of erosion and accretion zones. The sedimentary budget is not calculated because of uncertainties on the volume induced by the presence of the wandering river (shaded on figures).

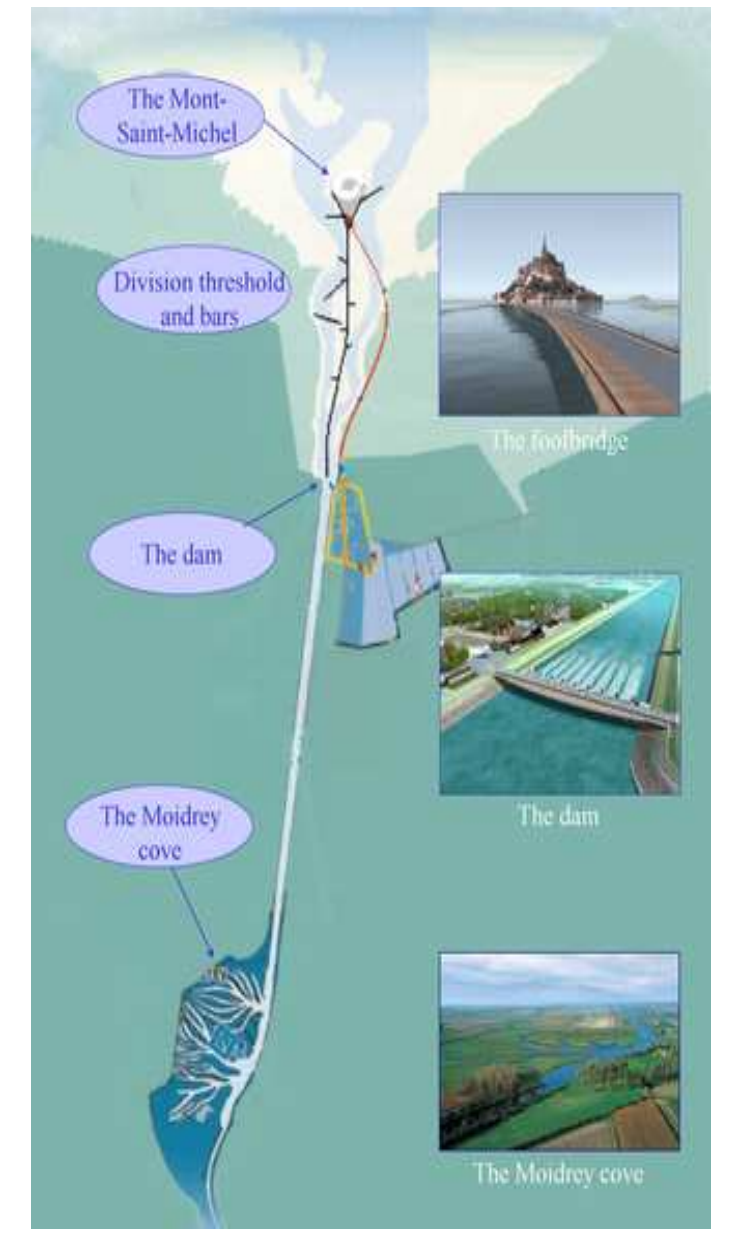

Fig. 2. Works in the "Rétablissement du caractère maritime du Mont-Saint-Michel" project (view of artist) 
The study of the altimetric evolution of the intertidal area for a long period will allow the calculation and confirmation of the global sedimentation rates.

\section{Results}

Sedimentary budgets are calculated, and we deduce the average annual sedimentation rate from it.

In 1997, there is a sedimentary volume of $\sim 284.8 .10^{6} \mathrm{~m}^{3}$ above the reference plan, and in 2002 , it is $\sim 286.6 .10^{6} \mathrm{~m}^{3}$. So the sedimentation rate in the first period is $+343000 \mathrm{~m}^{3} /$ year (Fig. 3). Erosion zones correspond to sweeping areas of the Couesnon, Sée and Sélune Rivers. This represents $8.9 .10^{6} \mathrm{~m}^{3}$, with local erosion relatively important $(-0.5$ to $-1.5 \mathrm{~m})$. Accretion represents $10.7 .10^{6} \mathrm{~m}^{3}$, and is globally located on the "Big Bank " (i.e. $500 \mathrm{~m}$. in the North of the Mont-Saint-Michel) and at the North feet of the Mont-Saint-Michel $(+0.5$ to $+1 \mathrm{~m}$.).

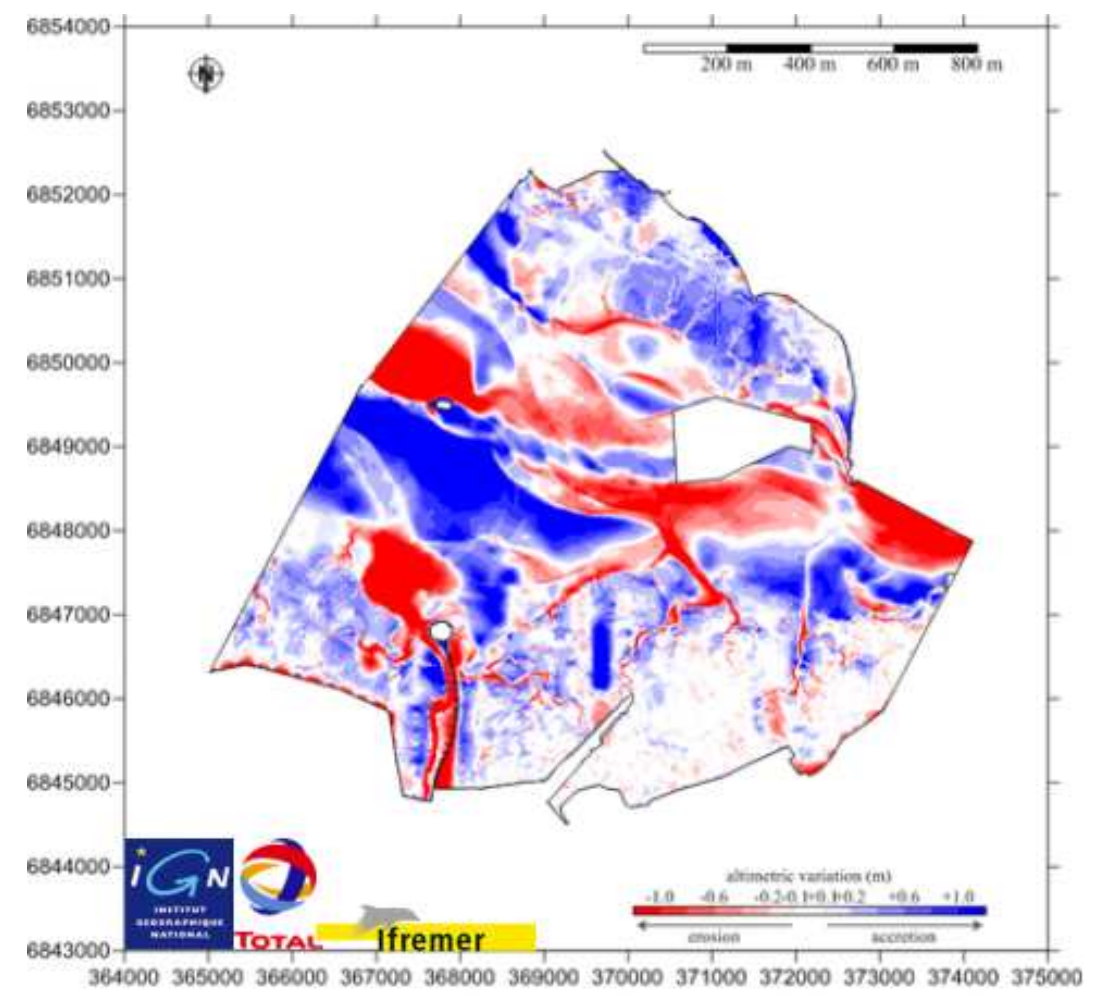

Fig. 3. altimetric comparison 1997-2002

In 2007 , the sedimentary volume is $\sim 287.3 .10^{6} \mathrm{~m}^{3}$. So during the $2002 / 2007$ period, the average sedimentation rate is $+155000 \mathrm{~m}^{3} /$ year (Fig. 4). Erosion represents $10.8 .10^{6} \mathrm{~m}^{3}$; also located in the sweeping areas of the rivers; while accretion is $11.6 .10^{6} \mathrm{~m}^{3}$, situated in the central part of the "Petite Baie » (i.e. the eastern part of the axis Champeaux / La ChapelleSte-Anne) and in the North of the East salt meadow $(+2 \mathrm{~m})$. 


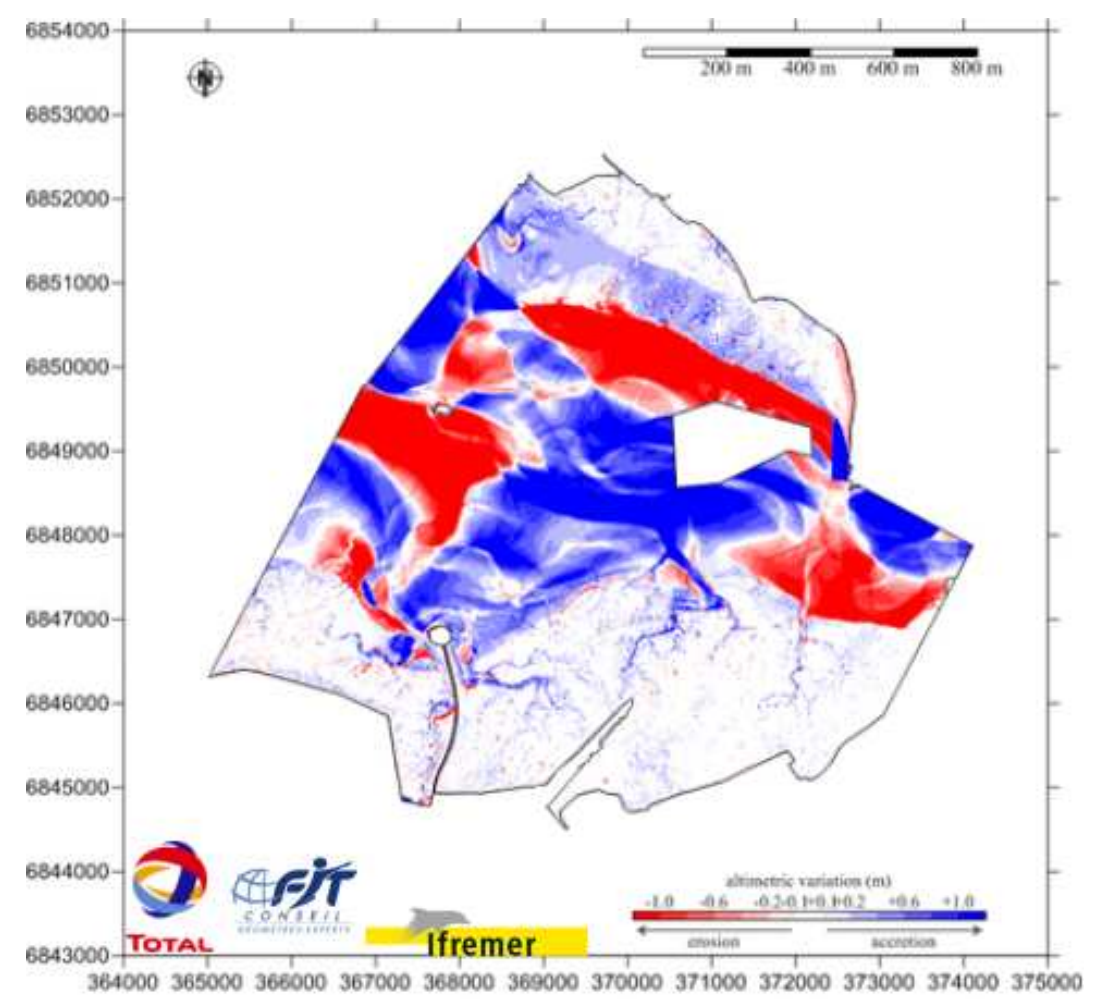

Fig. 4. Altimetric comparison 2002-2007

In February 2009, the sedimentary volume is $\sim 288.6 .10^{6} \mathrm{~m}^{3}$ leading to an average sedimentation rate of $+653000 \mathrm{~m}^{3} /$ year between 2007 and 2009. Erosion amounts to 7.4.106 $\mathrm{m}^{3}$ and accretion to $8.7 .10^{6} \mathrm{~m}^{3}$ (Fig. 5). Erosion zones are wandering areas of the river and the feet of the West salt meadow $(-1 \mathrm{~m})$ and accretion zones are situated in the central part of the bay, near Tombelaine Rock, and in the North of the East salt meadow $(+1 \mathrm{~m})$.

Because of uncertainties due to the movements of the Couesnon River, and so the involved sedimentary volumes, the comparison between two successive surveys (Lidar or terrestrial scanner) is qualitative. It allows to locate erosion and accretion zones and to appreciate their mobility. These comparisons are made between:

i) February 2009 - July 2009 (5 months). The accretion zone is situated in the ancient position of the Couesnon River (Fig. 6), in the main draining channel of the east salt meadow and on the "Big Bank". Altimetric variations are quite important $(+1 \mathrm{~m})$. North parts of the East and West salt meadows, and the North feet of the Mont-Saint-Michel, are eroded by the Couesnon River. These erosions are remarkable, especially at the NNE part of the area, where it is $\sim-1 \mathrm{~m}$ on a $100 \mathrm{~m}$ wide zone. 


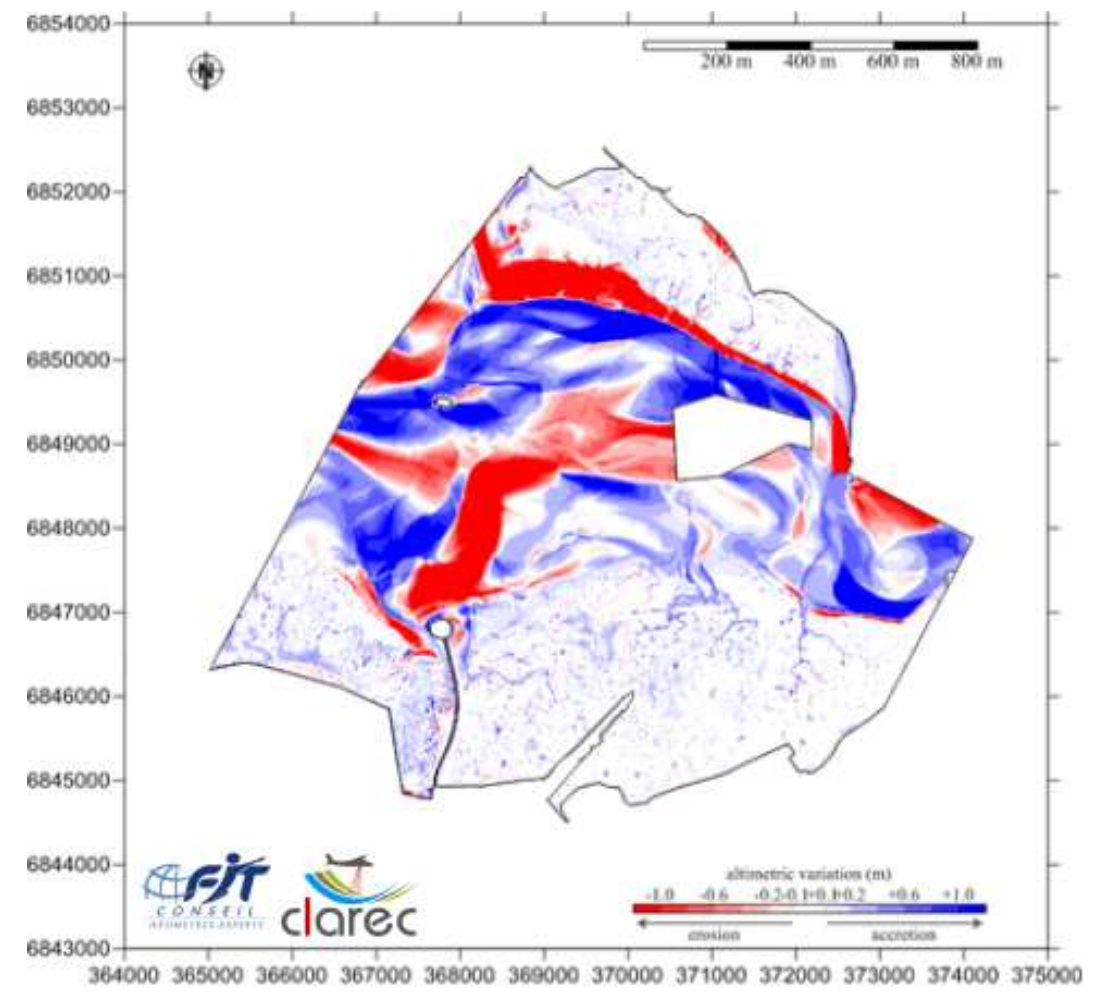

Fig. 5. Altimetric comparison 2007-2009

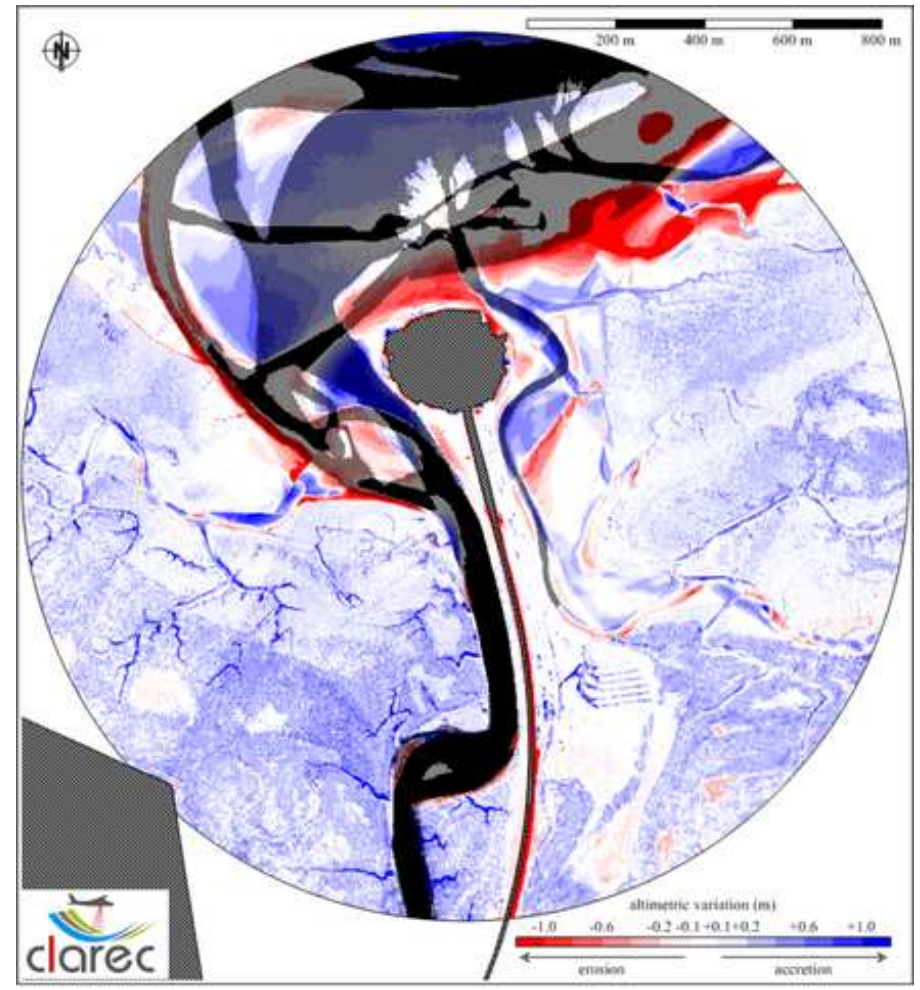

Fig. 6. Altimetric comparison 02-09 / 07-09 
ii) July 2009 - August 2009 (Fig. 7). Only in one month, erosion is really important (-1 m). The Western part of the Mont-Saint-Michel is also eroded although a bank appears $(+0.6$ to $+1 \mathrm{~m})$ just next size down.

iii) August 2009 - October 2009 (2 months). Erosion seems as important as accretion (Fig. 8). The borders of the salt meadows are always eroded, and the main draining channels too $(-1 \mathrm{~m})$. The "Big Bank" is growing $(+0.6$ to $+1 \mathrm{~m})$. Just north of the erosion zone of the West salt meadow, there is accretion (till $+1 \mathrm{~m}$ ). The bank in the Southwest of the Mont-SaintMichel is still growing $(+0.6$ to $+1 \mathrm{~m})$. When the September Lidar survey will be processed, the sample rate will be reduced at one month for this period.

iv) October 2009 - January 2010 (3 months). During this period, accretion prevails in terms of area (Fig. 9). Salt meadows are still eroded by the river. Erosion is also visible in the concave part of the meanders (up to $-1 \mathrm{~m}$ ). The bank at the Southwest rises and enlarges. An accretion zone appears at the Northwest feet of the Mont-Saint-Michel.

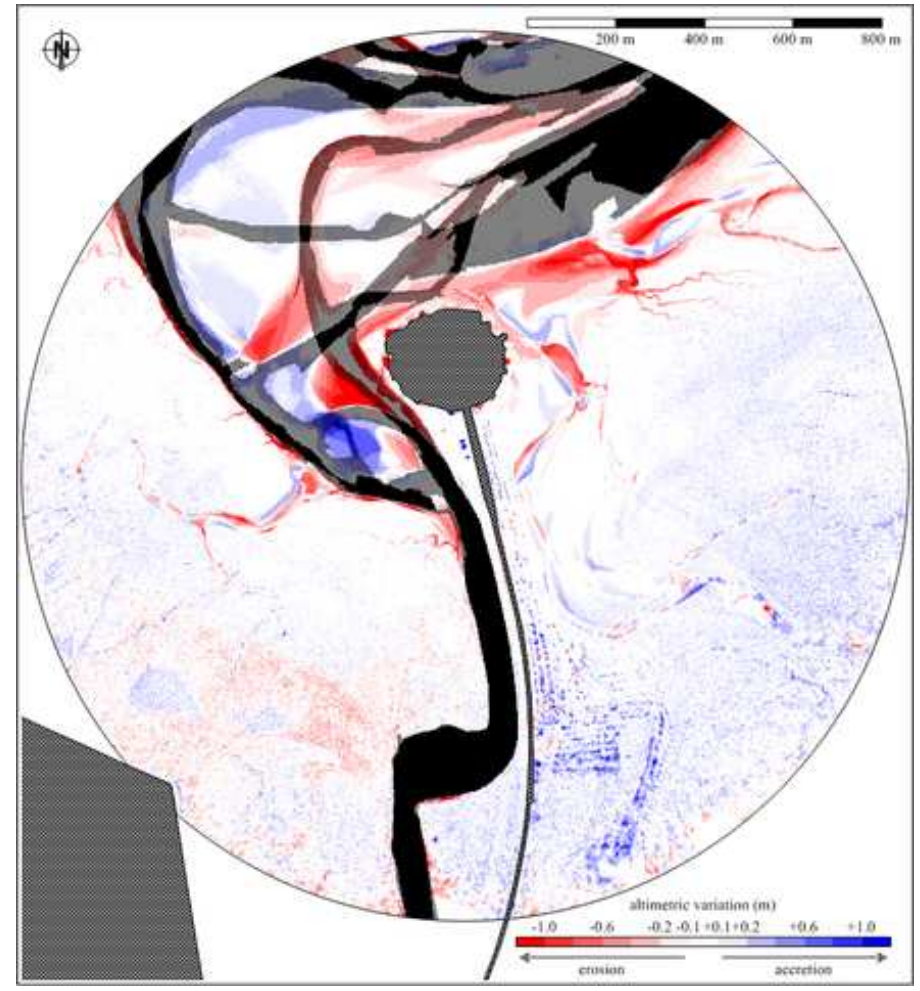

Fig. 7. Altimetric comparison 07-09 / 08-09

v) January 2010 - March 2010 (2 months). At this winter end, the main draining channel of the East salt meadow seems extremely eroded (more than $-1 \mathrm{~m}$ ), as the North of this salt meadow (Fig. 10). The same evolution but in a less proportion is observed at the West. The Couesnon River forms a new branch, so the "Big Bank" is eroded in its South part. The Southwest bank seems to enlarge $(+0.4$ to $+0.8 \mathrm{~m})$ towards West and North although its East and North parts are eroded $(-0.2$ to $-0.6 \mathrm{~m})$. There has been a measurement problem on the March survey, that why we can see a scanning effect on the Fig. 10 and Fig. 11. 


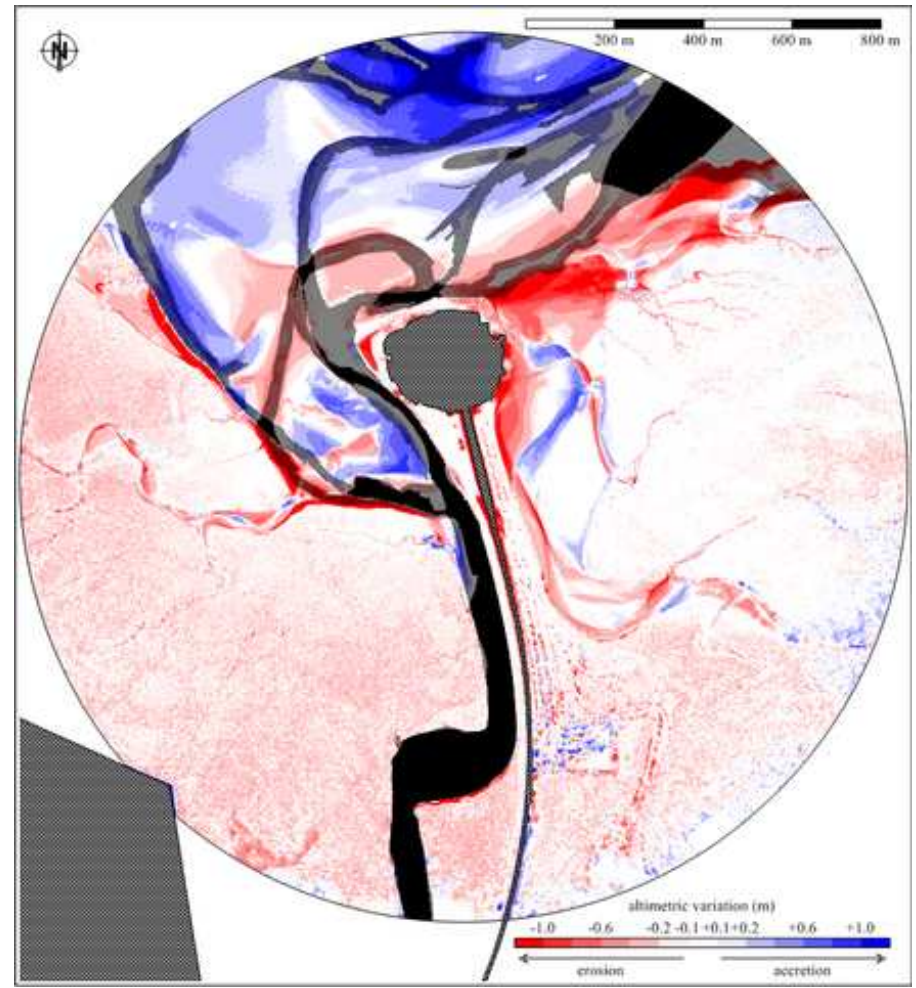

Fig. 8. Altimetric comparison 08-09 / 10-09

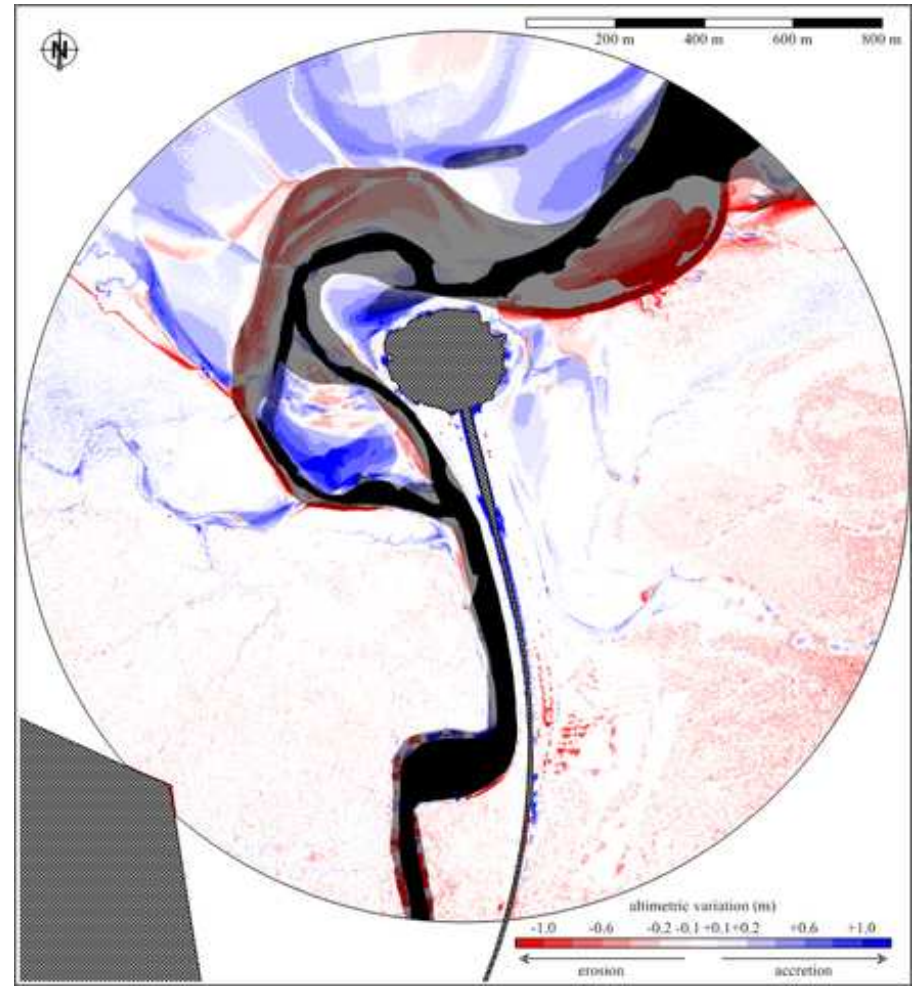

Fig. 9. Altimetric comparison 10-09 / 01-10 
vi) March 2010 - May 2010 (2 months). Erosion and accretion zones seem the same as the previous period, except the general erosion of the Southwest bank $(-0.2$ to $-0.6 \mathrm{~m})$ and the accretion $(+0.6 \mathrm{~m})$ in the main draining channel of the East salt meadow (Fig. 11). The "Big Bank" is eroded in its Southwest part $(-1 \mathrm{~m})$ but in accretion in its Southeast part $(+1 \mathrm{~m})$. The Northwest part of the Mont-Saint-Michel is in accretion $(+0.6 \mathrm{~m})$. When the April Lidar survey will be processed, the sample rate will be reduced at one month for this period.

\section{Discussion}

First we can see that sedimentary inputs are variable in time, and this even before the starting of the dam. The smallest annual sedimentation rate of $155000 \mathrm{~m}^{3} / \mathrm{year}$, observed during the 2002/2007 period, is 2.3 and 3.5 smaller than the values computed between 1997 and 2002 and from 2007 to 2009 respectively. Those inputs have a sea origin as there is no significant sedimentary contribution coming from land. These results show the accretional global tendency of the system. The variability of inputs raises the question of the real origin of the sediments: from the deep sea, sediments reworked on the field zone... Then, we can wonder on the physical processes at the origin of the mobilisation of such variable amounts of sediments. The calculation of sedimentary budgets and associated uncertainties from terrestrial laser scanning have to be realised to appreciate the budget evolution at a shorter time scale than that of the season.

This regular survey shows the contrasted effects of the flushes realised at the dam of La Caserne village. Since February 2009, the Couesnon River erodes more and more the salt meadows (West and East). But a huge bank - the Big Bank - rises up as another one at the southwest part of the Mont-Saint-Michel. Those banks constrain the Couesnon River in its channel. Studies show that the natural and global dynamic of the Couesnon River obeys to a 18.6-years lunar cycle (the Saros cycle). When we are in the ascendant phase of the cycle, the Couesnon River shifts its North general position to the East; when the phase is descending, it moves to the West. So it is supposed that the actual position of the river will shift to the West in the next descending phase, i.e. from the year 2015. Before this period, the Couesnon River is not likely to take a North and even West direction which may favour the erosion of the "Big Bank". Nowadays, the flushes only impacts on the West part of the Mont-Saint-Michel. In 2014 the new footbridge will be put in service, so the East part of the Mont-Saint-Michel will also be served. With a flush effect from both directions of the MontSaint-Michel, the behaviour of the river could be modified.

An other striking result is the appreciation of the evolution of the vegetation cover and efficiency of the drainage channels. It is growing between the end of the winter and the middle of the summer (except for the March 2010 - May 2010 comparison); and the vegetation cover roof is decreasing in autumn. The drainage channels are very active at the 


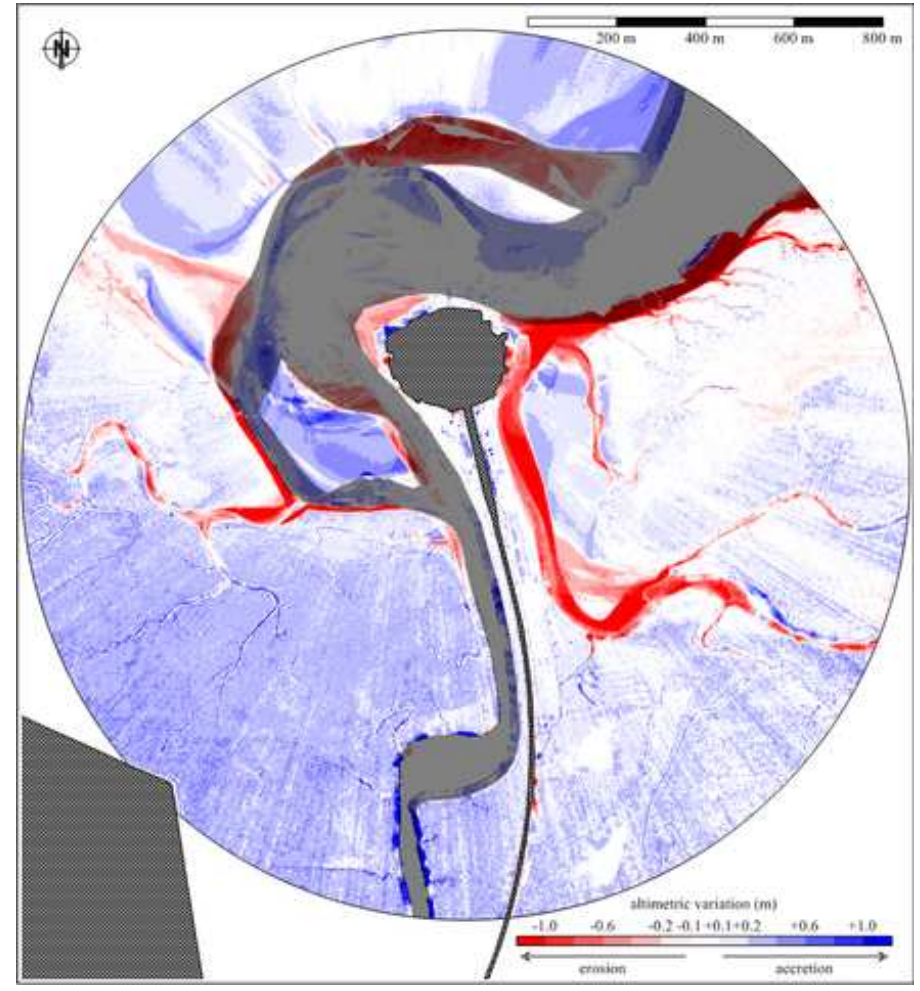

Fig. 10. Altimetric comparison 01-10 / 03-10

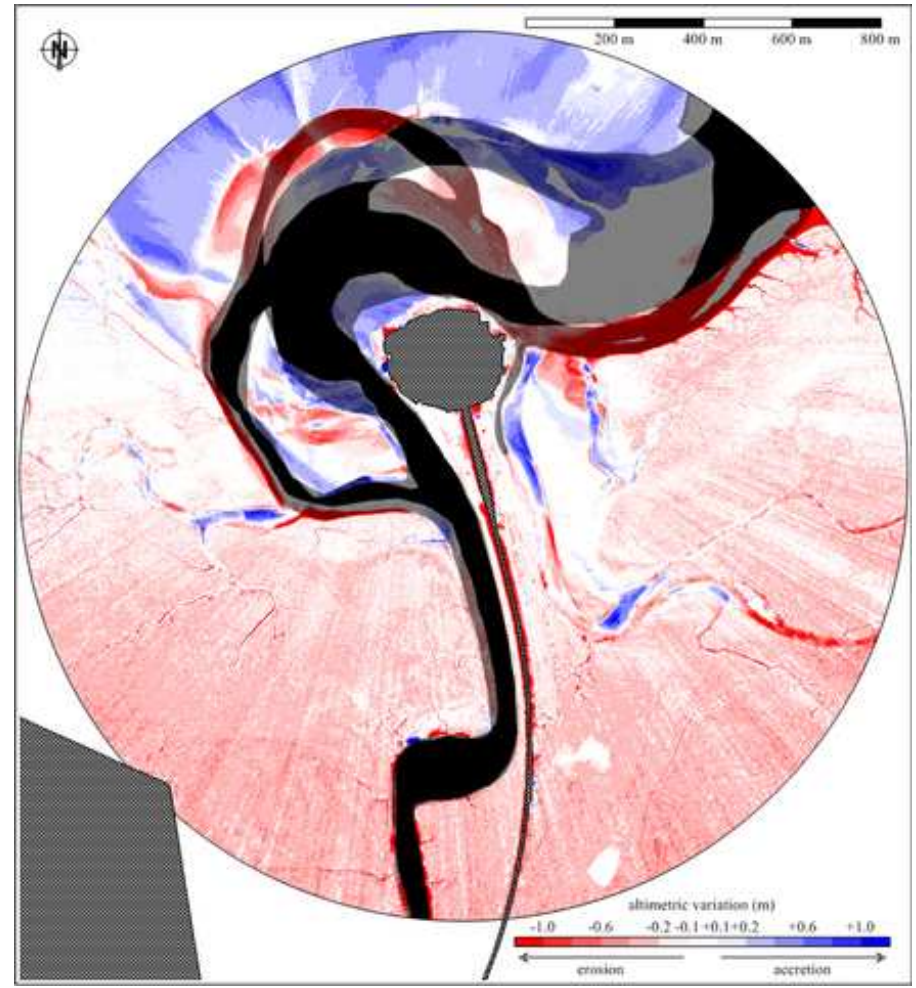

Fig. 11. Altimetric comparison 03-10 / 05-10 
end of the winter and the end of the summer. That reflects the meteorological conditions, because pluviometry is more important at these moments of the year in the "Petite Baie".

\section{Conclusion}

Our study shows that erosion and deposition on the tidal marsh have a considerable temporal and spatial variability. It is very important to have an adequate spatial and temporal sampling resolution to capture this variability (Proosdj et al., 2006). The use of laser techniques allows this sampling rate, that could not be achieved by other techniques (spatial resolution reduced by the complexity and inhospitality of such an environment...). Results, in their variety, are especially useful to the dam administrators. They can see what is the response of the environment to the flushes, so they can control the flushes to have the expected effect. When the functioning of the dam will be complete (i.e. when the footbridge will be built and the seawall road will be destroyed) the Couesnon River behaviour could be modified. The continuation of this study will allow to appreciate the new functioning of the dam and its effect on sediments in the "Petite Baie".

More generally, such studies are useful to improve the settlement of coastal dwellers and to better understand the aftermath of the implantation of coastal engineering.

\section{References}

Billeaud, I., Tessier, B., Lesueur, P., Caline, B. (2007). Preservation potential of highstand coastal sedimentary bodies in a macrotidal basin: Example from the Bay of Mont-SaintMichel, NW France. Sedimentary Geology 202, pp. 754-775.

Bonnot-Courtois, C., Caline, B., L'Homer, A., Le Vot, M. (2002). La baie du Mont-SaintMichel et l'estuaire de la Rance; Environnements sédimentaires, aménagements et évolution récente. Mémoire Elf-Aquitaine 26, 256 p.

Cayocca, F., Dussauze, M., Le Hir, P., Bassoullet, P., Jestin, H. (2006). Modélisation hydrosédimentaire de la Baie du Mont Saint-Michel, IXèmes Journées Nationales Génie Civil Génie Côtier, 12-14 septembre 2006, Brest.

Larsonneur, C. (1989). La baie du Mont-Saint-Michel. Bulletin de l'Institut de Géologie du Bassin d'Aquitaine 46, pp. 5-73.

Larsonneur, C. (1994). The Bay of Mont-Saint-Michel : A sedimentation model in a temperate macrotidal environment. Senckenbergiana maritima 24 (1/6), pp. 3-63.

Laboratoire Central d'Hydraulique de France (1971). La baie du Mont-Saint-Michel : études sédimentologiques et hydrologiques. Rapports inédits. Maisons-Alfort.

Le Rhun, J. (1982). Etude physique de la baie du Mont-Saint-Michel. Thèse de doctorat, Paris 1, $243 \mathrm{p}$. 
Mason, D.C., Scott, T.R., Dance, S.L. (2010). Remote sensing of intertidal morphological change in Morecambe Bay, U.K., between 1991 and 2007. Estuarine, Coastal and Shelf Science 87, pp. 487-496.

Migniot, C. (1997). Rétablissement du caractère maritime du Mont-Saint-Michel. Synthèse générale des connaissances sur les problèmes hydrosédimentaires en baie du Mont-SaintMichel. Rapport Mission Mont-Saint-Michel, DDE Manche, 89 p.

Neumeier, U., Amos, C.L. (2006). The influence of vegetation on turbulence and flow velocities in European salt marshes, Sedimentology 53, pp. 259-277.

Pingree, R.D., Griffiths, D.K. (1979). Sand transport paths around the British Isles resulting from the M2 and M4 tidal interactions. Journal of the Marine Biology Association U.K. 59, pp. 497-513.

Proosdj, D., Ollerhead, J., Davidson-Arnott, R.G.D. (2006). Seasonal and annual variations in the volumetric sediment balance of a macro-tidal salt marsh. Marine Geology 225, pp. 103-127.

Tessier, B. (1993). Upper intertidal rhythmites in the Mont-Saint-Michel Bay (NW France): Perspectives for paleoreconstruction. Marine Geology 110, issues 3-4, pp. 355-367.

\section{Acknowledgements}

We thank all the technique staff that participates actively in this study. This study is supported by research grants from the "Syndicat Mixte de la Baie du Mont-Saint-Michel" and the State (Basse-Normandie Region). 